\title{
Information for authors and readers
}

Manuscript submission: Please submit manuscripts online through the MOR ScholarOne Manuscripts site at http://mc.manuscriptcentral.com/mor. For more information and style instructions see http://journals.cambridge.org/mor/IFC.

Subscriptions: Management and Organization Review is published in March, June, September and December. The 2017 price for an online subscription for institutions is \$693 in the USA, Canada, and Mexico; UK £380 + VAT elsewhere. Individuals are encouraged to join the International Association for Chinese Management Research to obtain a subscription. Subscription correspondence and address changes should be sent to: Cambridge University Press, 100 Brook Hill Drive, West Nyack, NY 10994, USA, email subscriptions_newyork@cambridge.org, for customers in the USA, Canada, or Mexico. Customers elsewhere should contact: Cambridge University Press, The Edinburgh Building, Shaftesbury Road, Cambridge CB2 8RU, UK, email journals@cambridge.org. Single issues and individual articles to be purchased and rented are also available through Cambridge University Press.

International Association for Chinese Management Research members: Management and Organization Review is the journal of the International Association for Chinese Management Research, an academic organization that serves scholars, students, managers, and consultants who are interested in advancing their knowledge about organizational management in the Chinese context. IACMR membership includes online access to all issues of the journal with the option of print copies. Individuals can become members at http://www.iacmr.org

Permissions information: All rights reserved. No part of this publication may be reproduced, in any form or by any means, electronic, photocopying, or otherwise, without permission in writing from Cambridge University Press. Policies, request forms and contacts are available at: http:// journals.cambridge.org/action/rightsAndPermissions. Permission to copy (for users in the USA) is available from Copyright Clearance Center http://www.copyright.com, email info@copyright.com.

Advertising: To advertise in the journal email USAdSales@cambridge.org or telephone +1 (212) 3375053 in the USA, Canada or Mexico; email ad_sales@cambridge.org or telephone +44 (1223) 325083 in the rest of the world.

Abstracts and indexing: Indexed in ABI/INFORM Database (ProQuest), ABI/INFORM Global (ProQuest), Academic OneFile (GALE Cengage), ArticleFirst (OCLC), Business Source Complete (EBSCO Publishing), Business Source Corporate (EBSCO Publishing), Current Contents: Social \& Behavioral Sciences (Thomson Reuters), Environmental Sciences \& Pollution Management (ProQuest), Journal Citation Reports/Social Science Edition (Thomson Reuters), ProQuest Central (ProQuest), ProQuest Central: Professional Edition (ProQuest), ProQuest Discovery (ProQuest), PsycINFO/Psychological Abstracts (APA), RePEc: Research Papers in Economics, SCOPUS (Elsevier), Social Sciences Citation Index (Thomson Reuters), Web of Science (Thomson Reuters)

Management and Organization Review is published by Cambridge Journals on behalf of the International Association for Chinese Management Research. The journal is included in the Cambridge Journals Online service and can be found at http://journals.cambridge.org/mor.

ISSN: $1740-8776$

E-ISSN: $1740-8784$

(C) International Association for Chinese Management Research 


\title{
Management and Organization Review
}

\author{
Sponsored By \\ Peking University and Fudan University
}

CONTENTS

Volume 13 Issue 4

Letter from the Editor

693

ARIE Y. LEWIN

Perspective

Chi Yue Chiu

Culture Matters: A Perspective Advancing Cross-Cultural and Indigenous Research

Special Issue Introduction

Michael W. Morris, Zhen Xiong (George) Chen, Lorna Doucet, and Yaping Gong

A Giant of Cultural Research: Seeing Further from the Shoulders of Kwok Leung

Special Issue Articles

Jingjing Yao, Jimena Ramirez-Marin, Jeanne Brett, Soroush Aslani, and Zhaleh Semnani-Azad

A Measurement Model for Dignity, Face, and Honor Cultural Norms

Peter B. Smith

Cultural Values Versus Cultural Norms as Predictors of Differences in Helping Behaviors and in Emotion Regulation:

A Preliminary Nation-Level Test Related to the Leung-Morris Model

Xiao-Jun Xu and Xiao-Ping Chen

Unlocking Expatriates' Job Creativity: The Role of Cultural Learning, and Metacognitive and Motivational

Cultural Intelligence

Zhi-Xue Zhang ANd XIN Wei

Superficial Harmony and Conflict Avoidance Resulting from Negative Anticipation in the Workplace

Ali F. Ünal, Chao C. Chen, and Katherine R. Xin

Justice Climates and Management Team Effectiveness: The Central Role of Group Harmony

Kimmo Eriksson, Pontus Strimling, Per A. Andersson, Mark Aveyard, Markus Brauer,

Vladimir Gritskov, Toko Kiyonari, David M. Kuhlman, Angela T. Maitner, Zoi Manesi,

Catherine Molho, Leonard S. Peperkoorn, Muhammad Rizwan, Adam W. Stivers, Qirui Tian,

Paul A. M. Van Lange, Irina Vartanova, Junhui Wu, and Toshio Yamagishi

Cultural Universals and Cultural Differences in Meta-Norms about Peer Punishment

Chi-Ying Cheng And Ying-Yi Hong

Kiasu and Creativity in Singapore: An Empirical Test of the Situated Dynamics Framework

Dialogue, Debate, and Discussion

Greg Clydesdale with Introduction by Liisa Välikangas

Western Perceptions of Chinese Business: Sun Tzu and the Misuse of History

Runtian Jing And Mei Dong

Management Scholars' Learning from History: Direct vs. Indirect Approach

Peter Ping Li and Monsol Young

How to Approach the Ancient Chinese Wisdom? A Commentary Concerning Sun Tzu's The Art of War

\section{(C) InternationalAssociationfor Chinese ManagementResearch}

